\title{
Cell volumes of normal and malignant mononuclear cells
}

\author{
ELIZABETH H CHAPMAN, ANTHONY S KUREC, FREDERICK R DAVEY
}

From the Division of Clinical Pathology, State University of New York, Upstate Medical Center, 750 East Adams Street, Syracuse, New York 13210

SUMmARY The cell volumes of mononuclear cells, T lymphocytes, B lymphocytes, and monocytes from the peripheral blood of 20 normal individuals were compared to neoplastic lymphoid cells from 14 patients with chronic lymphocytic leukaemia (CLL), 20 individuals with acute lymphocytic leukaemia (ALL), and 18 cases of non-Hodgkin's lymphoma (NHL). Normal T cells were obtained by rosetting mononuclear cells with sheep erythrocytes followed by centrifugation on a gradient composed of Ficoll and diatrizoate salts. Monocyte populations were prepared by adhering mononuclear cells to plastic dishes and $\mathrm{B}$ cells were obtained by the depletion of $\mathrm{T}$ lymphocytes and monocytes from a mononuclear cell population. Cell volumes were determined on a Coulter Counter Model $\mathrm{H}_{4}$ Channelyzer. In normals, the average mean cell volume (MCV) of $\mathrm{T}$ lymphocytes was smaller than B lymphocytes and the average MCV of B lymphocytes was smaller than the average MCV of monocytes $(\mathrm{p}<0.05)$. The average MCV of lymphocytes from patients with CLL was smaller than the average MCV of normal B cells $(p<0.01)$. The average MCV of lymphoblasts from cases of ALL was larger than the average MCV of normal peripheral blood lymphocytes $(p<0.01)$. In addition, the size of lymphoblasts showed great variation within and among cases of ALL. The MCV of lymphocytes from most cases of NHL was larger than the MCV of lymphocytes from reactive lymph nodes and from the peripheral blood of normal individuals. An association was observed between the MCV of neoplastic cells and the classification according to Rappaport. We believe that the measurement of lymphoid cell volumes may be helpful in the diagnosis and prognosis of patients with a variety of lymphoproliferative disorders.

The determination of cell size has been a common and useful parameter employed in the diagnosis of various haematological malignancies. The differentiation of acute lymphocytic leukaemia from acute myelogeneous leukaemia can be distinguished in part by cell size. ${ }^{1}$ The classifications of lymphomas by Rappaport, ${ }^{2}$ Dorfman, ${ }^{3}$ and Lukes and Collins ${ }^{4}$ are based largely on the size of the cell. There have been studies $^{56}$ attempting to correlate the size of neoplastic lymphoid cells with the prognosis of the patient. In some studies, the size of the cells was determined by measuring the cell diameters using an eyepice micrometer. ${ }^{5}$ This technique is tedious, and only large size differences may be accurately identified. In addition, the cell size may be artificially altered by drying, fixatives, dehydration and flattening of cells on glass surfaces.

Because of these limitations, automated and semiautomated systems for cell volume analysis have been

Accepted for publication 27 April 1981 developed and the volume of many different cells in isotonic solutions has been determined. ${ }^{7-18}$ However, the volume of normal peripheral blood $\mathrm{T}$ and $\mathrm{B}$ lymphocytes, plastic adherent monocytes and a variety of neoplastic cells have not been well established using an automated system.

The purpose of this report is to present our data regarding the size of normal $T$ cells, $B$ cells, and monocytes and neoplastic cells from a variety of malignant disorders using an electronic instrument system (Coulter Model $\mathrm{H}_{4}$ Channelyzer) which provides rapid unbiased volume measurements for thousands of cells.

\section{Material and methods}

SOURCES OF CELL POPULATIONS

Normal peripheral blood samples were obtained from 10 female and 10 male hospital employees ranging in age from 20 to $40 \mathrm{yr}$. Blood, bone marrow, and lymph node samples from patients with chronic lymphocytic 
leukaemia (CLL), acute lymphocytic leukaemia (ALL) and non-Hodgkin's lymphoma (NHL) were obtained with informed consent as part of routine diagnostic procedures, or during clinical follow-up visits.

The diagnosis of CLL was established in an adult patient when a persistent absolute lymphocytosis $\left(>15000 / \mu \mathrm{l}\left(>15 \times 10^{9} / \mathrm{l}\right)\right)$ was observed in association with a bone marrow aspirate containing over $50 \%$ mature lymphocytes without more than $5 \%$ lymphoblasts.

The diagnosis of ALL was determined by the presence of lymphoblasts in the peripheral blood and lymphoblasts in the bone marrow (mean of $85 \%$ ). The cytoplasm of the lymphoblasts was negative for the presence of peroxidase ${ }^{19}$ and Sudan black $\mathbf{B}^{20}$ material but, was usually positive with the periodicacid Schiff (PAS) reagent. ${ }^{21}$

The diagnosis of NHL was established on tissue biopsies according to the criteria and classification of Rappaport. ${ }^{2}$

FRACTIONATION OF CELLS

Samples of venous blood $(20 \mathrm{ml})$ were drawn into heparinised Vacutainer Tubes (Becton-Dickinson Co, Rutherford, NJ, 07070) or heparinised syringes, mixed, and promptly layered over $10 \mathrm{ml}$ of Lymphocyte Separation Medium (LSM; 6.2 g Ficoll and $9.4 \mathrm{~g}$ sodium diatrizoate, Litton Bionetics, Inc, Kensington, Md., 20795) in a $50 \mathrm{ml}$ centrifuge tube and spun for $30 \mathrm{~min}$ at $400 \mathrm{~g}$. The LSM provided a gradient for isolation of the peripheral blood mononuclear (PBM) cells at the plasma/LSM interface. ${ }^{22}$ The PBM cell layer was removed, and washed three times with $50 \mathrm{ml}$ Hanks' balanced salt solution (HBSS; Gibco, Buffalo, NY, 14072) and then centrifuged for $10 \mathrm{~min}$ at $200 \mathrm{~g}$. The washed PBM cells were resuspended at $5 \times 10^{6} / \mathrm{ml}$ in HBSS for sizing analysis, or further fractionated to give $\mathrm{T}$ cell, B cell, or monocyte enriched populations.

The procedure of Gmelig-Meyling and Ballieux ${ }^{23}$ permitted separation of PBM cells into populations of $T$ lymphocytes and non- $T$ cells on the basis of spontaneous rosette formation of $\mathrm{T}$ cells with sheep red blood cells (SRBC). PBM cells $\left(1.5 \times 10^{7} / \mathrm{ml}\right.$ concentration) and SRBC (15\% suspension) were suspended in modified Eagles minimum essential medium (MEM; Gibco, Buffalo, NY, 14072). The MEM solution was prepared using $100 \mathrm{ml}$ MEM with modified Earle's Salts, $3 \mathrm{ml}$ of $34.5 \%$ bovine serum albumin and $3 \mathrm{ml}$ of a $1 M$ HEPES solution. A total of $4 \mathrm{ml}$ of the cell suspension and $1.5 \mathrm{ml}$ of the SRBC suspension were mixed, overlayered on $4 \mathrm{ml} \mathrm{LSM} \mathrm{in} 16 \times 125 \mathrm{~mm}$ plastic tubes and immediately centrifuged at $1200 \mathrm{~g}$ for $30 \mathrm{~min}$. The specified centrifugal speed must be reached within the initial 20 seconds of centrifugation for maximum rosette formation and separation of $T$ and non- $T$ cells. Since the rosettes are carried into the pellet, the remaining interface layer of cells is depleted of $T$ cells and thus enriched for $B$ lymphocytes and monocytes. The non-T cells were washed twice with HBSS and resuspended at $5 \times 10^{6} / \mathrm{ml}$ in HBSS for sizing. The T-enriched pellet was well mixed with $3 \mathrm{ml}$ of Tris-ammonium chloride solution ( $\mathrm{pH} 6 \cdot 2-6 \cdot 4)$, and placed at $37^{\circ} \mathrm{C}$ in a waterbath for three minutes to lyse the SRBC. Tris- $\mathrm{NH}_{4} \mathrm{Cl}$ solution was prepared using one part Tris-buffer, pH 7.3 (Trizma $\mathrm{HCl}$ and Trizma base, Sigma Chemical Co, St Louis, MO 63178), to nine parts $0.83 \mathrm{~g} \% \mathrm{NH}_{4} \mathrm{Cl}$. The haemolysed pellet was then washed twice with HBSS, and the T-enriched cells were resuspended in HBSS at $5 \times 10^{6} / \mathrm{ml}$ for sizing. This method of separating $T$ lymphocytes from non- $T$ lymphocytes has been compared to the procedure of passing mononuclear cells over nylon wool columns and sedimenting non-adherent cells following incubation with sheep erythrocytes. The purity of the $\mathrm{T}$ and non-T cell populations is similar with both techniques. ${ }^{24-26}$

In a preliminary study, the use of $\mathrm{Tris}-\mathrm{NH}_{4} \mathrm{Cl}$ was shown not to affect the volume of lymphocytes. The volume of peripheral blood lymphocytes from twe individuals was measured before and after incuso bation with Tris- $\mathrm{NH}_{4} \mathrm{Cl}$ and the results showed no significant difference $(p>0.5)$.

To obtain a monocyte enriched population, $5 \mathrm{ml}$ of non-T cells at $2.0 \times 10^{7} / \mathrm{ml}$ in RPMI 1640 medium (Medical Associates Bioproducts, Walkersville, Md, 21793 ) with $20 \%$ fetal calf serum (FCS) were placed in a $15 \times 60 \mathrm{~mm}$ plastic Petri culture dish and allowed to incubate at $37^{\circ} \mathrm{C}$ (with $5 \% \mathrm{CO}_{2}$ and humidity) for 45 to $60 \mathrm{~min}$. Monocytes adhered to the surface of the dish, while most of the lymphocytes were gently washed out of the dish by adding approximately $5 \mathrm{ml}$ of RPMI with $20 \%$ FCS (pre-warmed to $37^{\circ} \mathrm{C}$ ), slowly tilting the dish, and discarding the supernatant wash fluid. The monocytes which adhered were then scraped from the dish bottom with a rubber policeman while rinsing the dish with HBSS without calcium and magnesium. This monocyte-enriched population was suspended in regular HBSS (containing calcium and magnesium) at $5 \times 10^{6} / \mathrm{ml}$ cell concentration for sizing.

Blood samples from CLL patients were collected and processed the same as the normal samples, except that enrichment for monocytes was not done. Lymphoblasts from patients with ALL were separated from other bone marrow or peripheral blood elements by layering the sample over LSM and centrifugation at $40 \mathrm{~g}$ for $30 \mathrm{~min}$. The interface population had greater than $95 \%$ lymphoblasts and 
immature lymphocytes. Lymph node and tissue specimens were teased with a scalpel into tiny (2-3 $\mathrm{mm}$ ) pieces and pressed through a fine gauge stainless steel mesh screen into a Petri dish while continuously rinsing with HBSS to keep the tissue moist. Cells recovered by this technique were then sized without fractionation into mononuclear subpopulations.

All cell suspensions in HBSS were diluted to approximately $1.0 \times 10^{6} / \mathrm{ml}$ in $20 \mathrm{ml}$ isotonic saline (Isoton, Coulter Electronics, Inc, Hialeah, FL, 33010) immediately before sizing.

\section{LYMPHOCYTE SURFACE MARKERS}

The number of $T$ lymphocytes was determined by assaying for non-immune rosette formation with sheep erythrocytes according to the method of Jondal et al. ${ }^{27}$

B lymphocytes were counted by detecting the number of lymphocytes with surface membrane immunoglobulins according to the method of Papamichail et al. ${ }^{28}$ One hundred microlitres of fluorescein isothiocyanate conjugated goat $\left(\mathrm{F}\left(\mathrm{ab}^{\prime}\right)_{2}\right.$ fragment) antihuman immunoglobulin (polyvalent; IgG, IgM heavy chains; $\kappa$ and $\lambda$ light chains) were added to $1 \times 10^{6}$ mononuclear cells in a microcentrifuge tube and incubated at $4^{\circ} \mathrm{C}$ for $45 \mathrm{~min}$. Unbound antiserum was removed by three oneminute washes with cold $0.01 M$ phosphate-buffered saline (PBS), pH 7.2 with $0.2 \%$ sodium azide at $3500 \mathrm{~g}$. The last cell button was resuspended in 0.05 $\mathrm{ml}$ PBS containing $\mathbf{4 0} \%$ glycerol, placed on a glass slide, coverslipped, sealed and stored at $-20^{\circ} \mathrm{C}$ until it was examined. A minimum of 200 cells was studied for surface fluorescence using an epiilluminated fluorescence microscope with a mercury arc lamp at $\times 1000$ magnification. The percentage of positive staining cells using antihuman polyvalent immunoglobulin serum was used to determine the total number of surface membrane immunoglobulin positive cells. The antisera against heavy and light chains were used in the diagnosis of lymphoproliferative disorders.

Monocytes were identified by the presence of a diffuse stain with alpha naphthyl acetate esterase. ${ }^{29}$

Using the above separation technique, we have shown that the $\mathrm{T}$ cell population contained over $90 \%$ $\mathrm{E}$ rosette-forming lymphocytes and was markedly depleted in B cells and monocytes. The monocyte population consisted of more than $90 \%$ alpha naphthyl acetate esterase positive cells, no $\mathrm{T}$ cells and $6 \%$ B lymphocytes. The B-enriched population contained $74 \%$ Ia positive cells, $42 \%$ surface membrane immunoglobulin positive cells, $5 \% \mathrm{~T}$ cells and $6 \%$ monocytes. ${ }^{30}$ Although the latter population is B cell-enriched, it presumably also contains $\mathrm{K}$ or $\mathrm{L}$ cells, null (non-B, non-T) cells and colony forming cells. ${ }^{3132}$ Since the latter cells contain "Ia-like" antigen but not surface membrane immunoglobulin, a discrepancy between these two markers exists.

T cell leukaemias and lymphomas were identified by the presence of neoplastic cells forming rosettes with sheep erythrocytes on Wright-Giemsa stained cytocentrifuged preparations. B cell lymphomas were diagnosed when a substantial number of tumour cells displayed surface membrane immunoglobulins and failed to form rosettes with sheep erythrocytes or display a diffuse stain for alpha naphthyl acetate esterase. The term "null cell" (non-B, non-T cell) proliferation was used when the neoplastic cells did not form rosettes with sheep erythrocytes, contain surface membrane immunoglobulin, or demonstrate alpha naphthyl acetate esterase.

\section{CHANNELYZER SYSTEM}

The Model $\mathrm{H}_{4}$ channelyzer system provides precise, high-resolution particle (cell) volume measurements. The measurement capability spans a volumetric range of $256: 1$-that is, uses 256 channels, with a resolving capacity of 1 in 256 .

To permit proper conversion of the digital words to recognisable size units $\left(\mu \mathrm{m}^{3}\right)$, calibration of the system was necessary. Polystyrene microspheres of uniform size $\left(10.01 \mu \mathrm{m}\right.$ diam, $525 \mu \mathrm{m}^{3}$ vol, Coulter Electronics, Inc, Hialeah, FL 33010) were used to calibrate the channelyzer according to the procedure outlined in the operator's manual. A scale factor of $4.494 \mu \mathrm{m}^{3}$ per channel was established. The program then used this scale factor to convert channel number to $\mu \mathrm{m}^{3}$. Over the 256 channel range, cells which fell between $4.5 \mu \mathrm{m}^{3}$ and $1152 \mu \mathrm{m}^{3}$ could be sized.

\section{DATA SELECTION FROM CHANNELYZER}

For each cell suspension, an initial accumulation run was performed with the end point of the accumulation preset via the Data entry/recall terminal at 2000 cells in any single channel. Although the total number of cells accumulated varied from sample to sample, the modal channel always contained 2000 cells. Usually the total number of cells analysed in one accumulation was greater than 40000 , but this depended, of course, on the heterogeneity of sizes within the sample. For the initial accumulation, a fairly wide size interval was preselected-that is, $100-600 \mu \mathrm{m}^{3}$.

A print out of the mean cell volume, standard deviation of the mean, modal volume, total counts in the interval, and the population differential histogram was obtained for each sample. From these 
initial data and the visual display of the accumulation on the Signal Processor, more narrow intervals of a particular peak or area of the histogram were defined. For example, the initial accumulation with the $100-600 \mu \mathrm{m}^{3}$ interval for a normal $\mathrm{T}$ cell depleted suspension would show two peaks; the major one consisted of B lymphocytes and a minor peak was composed of monocytes. The mean cell volume, standard deviation, modal volumes, total counts in the interval, and population histogram relating to each peak could be obtained by selecting the intervals $120-320 \mu \mathrm{m}^{3}$ for B lymphocytes and 321-600 $\mu \mathrm{m}^{3}$ for monocytes. The data obtained for the more narrowly defined peaks were used for further calculations and comparison of cell sizes.

\section{STATISTICAL METHODS}

The averages and standard deviations of the individual mean cell volumes (MCV), standard deviations of the mean (SD), coefficients of variation (CV) and modal volumes (MV) were determined for suspensions of normal and neoplastic lymphoid cells. When appropriate, the data were compared using Student's $t$ test, Duncan's multiple range test and the Dunnett's procedure. ${ }^{33}$

\section{Results}

\section{NORMAL PERIPHERAL BLOOD MONONUCLEAR} CELLS

Our fractionation techniques separated PBM cells into T lymphocyte-, monocyte- and B lymphocyteenriched cell populations. Table 1 shows the average \pm SD of the individual MCVs, SDs, CVs and MVs. In comparing the MCV of three cell populations from 20 normal donors, $T$ lymphocytes $\left(176 \pm 6 \mu \mathrm{m}^{3}\right)$ were significantly smaller $(\mathrm{p}<0.05)$ than B lymphocytes $\left(190 \pm 6 \mu \mathrm{m}^{3}\right)$ and $\mathrm{T}$ and $\mathrm{B}$ lymphocytes were smaller $(p<0.05)$ than monocytes $\left(413 \pm 21 \mu \mathrm{m}^{3}\right)$. The average modal volumes varied in a similar pattern to the MCV among the various lymphocyte subpopulations.

\section{CHRONIC LYMPHOCYTIC LEUKAEMIA}

The cell size was determined on B cell-enriched suspension from the peripheral blood of 14 cases of CLL (Table 1). The average mean cell volume (MCV) and mode were smaller than those observed with normal B lymphocytes $(\mathrm{p}<0.01)$. Lymphocyte populations from 9 of 14 cases of CLL were less than two standard deviations (SD) of the average MCV of normal B lymphocytes. In contrast, the MCVs of two cases were greater than 2 SDs of normal B lymphocytes (MCV $205 \mu \mathrm{m}^{3}$, MCV $210 \mu \mathrm{m}^{3}$ ). Clinically these patients with the largest MCVs were in stage IV according to Rai et al. ${ }^{34}$ The average $\mathrm{SD}$ around the MCV of cells from patients with CLL was similar to that observed with normal B cells $(\mathrm{p}>0.05)$.

ACUTE LYMPHOCYTIC LEUKAEMIA

The size of lymphoblasts was determined in 20 cases of ALL (Table 1). Samples were obtained from the bone marrow in 16 cases and from the peripheral blood in eight cases. In four cases, the samples were obtained from both bone marrow and peripherak blood. There was no significant difference betweete the size of lymphoblasts in the bone marrow and peripheral blood $(p>0.5)$. The average MCV of lymphoblasts from patients with ALL was $243 \pm 58$ $\mu \mathrm{m}^{3}$ and the average modal volume was $219 \pm 54$ $\mu \mathrm{m}^{3}$. The average $\mathrm{MCV}$ and modal volume of lymphoblasts from patients with ALL were larger than those of normal peripheral blood lymphocytes $(\mathrm{p}<0.01)$. Within an individual ALL population, the lymphoblasts size demonstrated greater variability than observed in normal PBM cells (Table 1) as evidenced by a larger average standard deviation

Table 1 Average mean cell volumes, standard deviations, coefficients of variation, modal volumes of normal mononuclear cells and of neoplastic lymphoid cells

\begin{tabular}{|c|c|c|c|c|c|}
\hline Cell type & $\begin{array}{l}\text { No of different } \\
\text { samples } \\
\text { measured }\end{array}$ & $\begin{array}{l}\text { Average } \\
\text { mean cell } \\
\text { volume }\left(\mu m^{3}\right)\end{array}$ & $\begin{array}{l}\text { Average } \\
\text { stondard } \\
\text { deviation of } \\
\text { each mean cell } \\
\text { volume }\end{array}$ & $\begin{array}{l}\text { Average } \\
\text { coefficient } \\
\text { of variation }\end{array}$ & $\begin{array}{l}\text { Average } \\
\text { modal volume } \\
\left(\mu m^{3}\right)\end{array}$ \\
\hline Normal mononuclear cells & 20 & $187 \pm 6$ & $38 \pm 9$ & $21 \pm 2$ & $175 \pm$ \\
\hline Normal T cells & 20 & $176 \pm 6$ & $34 \pm 3$ & $20 \pm 2$ & $166 \pm 9$ \\
\hline Normal B cells & 20 & $190 \pm 6$ & $42 \pm 2$ & $22 \pm 2$ & $176 \pm 17$ \\
\hline Normal monocytes & 20 & $413 \pm 21$ & $73 \pm 10$ & $18 \pm 2$ & $383 \pm 33$ \\
\hline Reactive lymph nodes & 6 & $186 \pm 25$ & $53 \pm 20$ & $27 \pm 9$ & $159 \pm$ \\
\hline Chronic lymphocytic leukaemia & 14 & $173 \pm 22$ & $38 \pm 14$ & $21 \pm 6$ & $148 \pm$ \\
\hline Acute lymphocytic leukaemia & 20 & $243 \pm 58$ & $52 \pm 12$ & $22 \pm 4$ & $219 \pm$ \\
\hline Poorly differentiated lymphocytic lymphoma & 8 & $212 \pm 41$ & $48 \pm 21$ & $22 \pm 6$ & $189 \pm 27$ \\
\hline Mixed histiocytic-lymphocytic lymphoma & 5 & $259 \pm 86$ & $75 \pm 42$ & $28 \pm 7$ & $247 \pm 146$ \\
\hline Burkitt's lymphoma & 3 & $400 \pm 87$ & $98 \pm 31$ & $23 \pm 9$ & $336 \pm 107$ \\
\hline Histiocytic lymphoma & 2 & 409 & 102 & 28 & 318 \\
\hline Hairy cell leukaemia & 2 & 395 & 74 & 19 & 358 \\
\hline
\end{tabular}


among blasts than normal PBM cells $(\mathrm{p}<0.01$ ). There was also greater variability among the different MCVs of lymphoblasts from patients with ALL than observed in the population of normal PBM cells. In addition, the MCVs of lymphoblasts from patients with ALL clustered into at least two and perhaps three groups $\left(<239 \mu \mathrm{m}^{3} ; 260-320 \mu \mathrm{m}^{3}\right.$; and $>320 \mu \mathrm{m}^{3}$; Fig. 1).

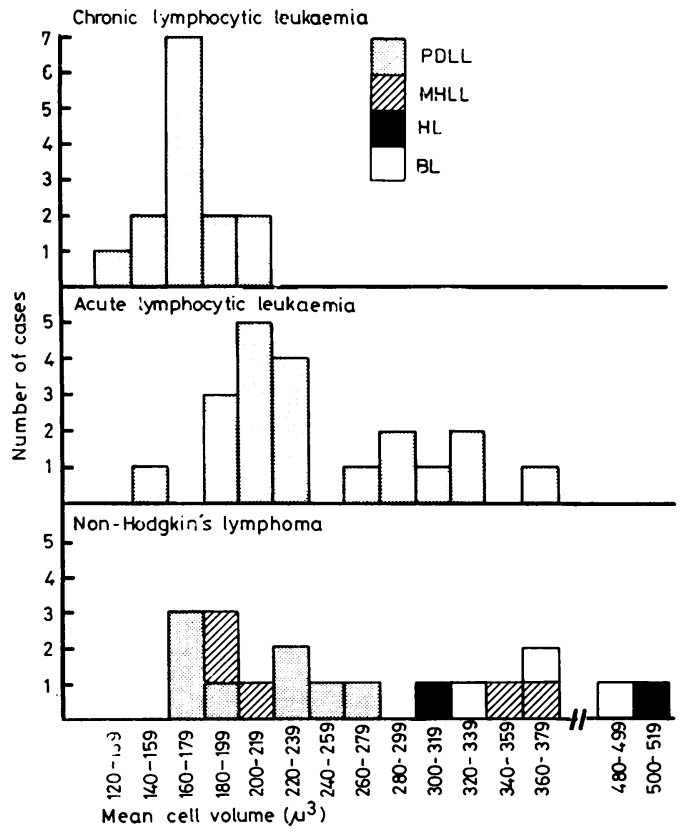

Fig. 1 Comparison of mean cell volumes of neoplastic lymphocytes from 14 cases of CLL, 20 cases of $A L L$, and 18 cases of NHL (PDLL = poorly differentiated lymphocytic lymphoma; $M H L L=$ mixed histiocytic lymphocytic lymphoma; $H L=$ histiocytic lymphoma; $B L=$ non-African Burkitt's lymphoma).

Lymphoblasts from bone marrow and peripheral blood films were classified according to the FAB cooperative group. ${ }^{35}$ Seven of 20 cases of ALL were considered to be of L2 morphology and 13 cases were of $\mathrm{L} 1$ morphology. The average MCV for L2 blasts was $259 \pm 57 \mu \mathrm{m}^{3}$ and the average $\mathrm{MCV}$ for $\mathrm{L} 1$ blasts was $236 \pm 50 \mu \mathrm{m}^{3}$ ( $\mathrm{p}>0.05$ ).

In four cases of ALL a bimodal population of lymphoblasts was noted on the channelyzer histogram and confirmed by bone marrow films. The MCVs of each pair are 184 and $366 \mu \mathrm{m}^{3}, 191$ and 330 $\mu \mathrm{m}^{3}, 152$ and $320 \mu \mathrm{m}^{3}$, and 188 and $293 \mu \mathrm{m}^{3}$. For convenience, these four cases were grouped and analysed according to the peak with the largest number of blasts.
NON-HODGKIN'S LYMPHOMAS

The size of lymphocytes from diagnostic lymph nodes of 18 cases of non-Hodgkin's lymphoma (NHL) are given in Table 1. The average MCV of lymphocytes from cases of poorly differentiated lymphocytic lymphoma (PDLL) were smaller than the average MCV of lymphocytes from cases of mixed histiocytic lymphocytic lymphoma (MHLL), histiocytic lymphoma (HL) and non-African Burkitt's lymphoma (BL). The average MCVs of all non-Hodgkin's lymphomas were larger than the average MCV of lymphocytes from six reactive lymph nodes and from the peripheral blood lymphocytes of 20 normal individuals $(\mathrm{p}<0.05)$. In addition, the average standard deviation within individual cases and the standard deviation among the cases of MHLL, HL and $\mathrm{BL}$ were larger than observed in the reactive lymph nodes and normal peripheral blood lymphocytes.

HAIRY CELL LEUKAEMIA

Two cases of hairy cell leukaemia were studied. The MCVs of the neoplastic cells were $373 \pm 66 \mu \mathrm{m}^{3}$ and $417 \pm 82 \mu \mathrm{m}^{3}$ respectively.

\section{COMPARISON OF MCVS ACCORDING TO}

LINEAGE

Neoplastic cells from various lymphoproliferative disorders were classified according to lymphocyte surface marker studies. Five cases of CLL, six of PDLL, five of MHLL, three of BL and two of HL were demonstrated to be of $\mathrm{B}$ cell lineage (Table 2). Nine cases of CLL were not completely evaluated for lymphocyte markers but, nevertheless, are listed as B cell proliferations. Three cases of ALL and one case of PDLL were T cell disorders. Neoplastic cells from 17 cases of ALL and one case of PDLL failed to display lymphocyte surface markers and were listed as null cell neoplasms (Table 2). In Fig. 2, the MCVs of normal and neoplastic cells were compared according to their lineage.

Table 2 Surface markers expressed in various lymphoproliferative disorders

\begin{tabular}{|c|c|c|c|}
\hline \multirow[t]{2}{*}{$\begin{array}{l}\text { Lymphoproliferative } \\
\text { disorders }\end{array}$} & \multicolumn{3}{|c|}{$\begin{array}{l}\text { Surface markers } \\
\text { (mean percentage positive } \pm \text { standard } \\
\text { error) }\end{array}$} \\
\hline & Erosettes* & $S M I g \dagger$ & $a N A E_{+}^{+}$ \\
\hline $\begin{array}{l}\text { T cell (4) } \\
\text { B cell }(21) \\
\text { Null cell }(18)\end{array}$ & $\begin{array}{r}77 \pm 8 \\
21 \pm 8 \\
2 \pm 1\end{array}$ & $\begin{array}{r}1 \pm 1 \\
73 \pm 4 \\
3 \pm 1\end{array}$ & $\begin{array}{l}<1 \\
<1 \\
<1\end{array}$ \\
\hline
\end{tabular}

*E rosettes = cells which form rosettes with sheep erythrocytes. †SMIg = surface membrane immunoglobulin. $\pm a$ NAE = alpha naphthyl acetate esterase. 


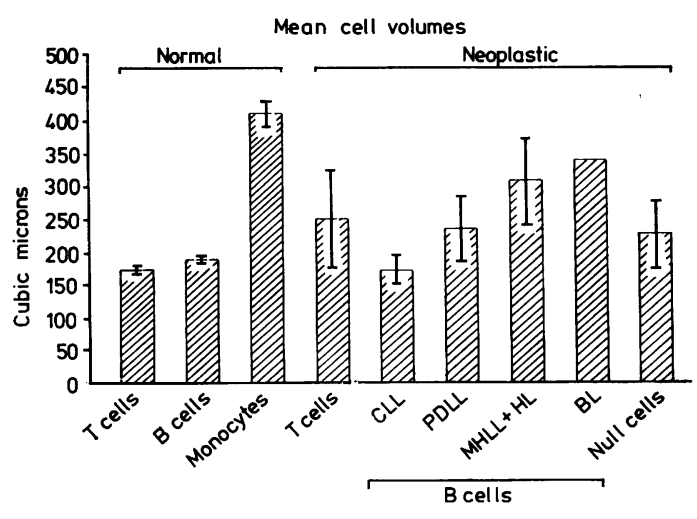

Fig. 2 Comparison of mean cell volumes of normal and neoplastic mononuclear cells according to their lineage. (See Fig. 1 for expansion of abbreviations.)

\section{Discussion}

The determination of cell size has been used as a diagnostic and prognostic criterion in the evaluation of lymphoproliferative disorders. ${ }^{1-5}$ Unfortunately the determination of cell size has been performed in most cases by a relatively crude microscopic technique. The current study compared the cell size of normal mononuclear subpopulations with suspensions of lymphoid cells from a variety of lymphoproliferative disorders.

Separation techniques produced minimal damage to samples, since the cells were maintained in balanced media throughout the procedure. The channelyzer permitted a well defined assay of cell volume since the width of each channel was less than $5 \mu \mathrm{m}^{3}$. The precise calibration, selection of electrical setting on the channelyzer to minimise cytoplasmic distortion, and the computation of cell volume statistics all blended to optimise the accuracy and reproducibility of this assay.

The current study demonstrated that normal peripheral blood T lymphocytes, B lymphocytes and monocytes had significantly different MCVs; a finding not previously reported. The measurement of unfractionated peripheral blood mononuclear cells was similar to other previous studies using similar separation and measuring techniques ${ }^{7836}$ but differed from studies using other methods for the collection, separation, and measurement of volume of blood cells. 89

In our study, the average MCV and modal volume of lymphocytes from patients with CLL were smaller than normal B lymphocytes. As a group, the lymphocytes from patients with CLL were homogeneous in size and showed no greater cell variation than normal B lymphocytes. In agreement with these findings, Ben-Sasson et al. ${ }^{18}$ obtained an MCV of 173 $\mu \mathrm{m}^{3}$ from one case of CLL (versus $197 \mu \mathrm{m}^{3}$ from normal lymphocytes). Braylan et $a .^{36}$ studied lymphocytes from six cases of CLL and found that the modal cell volumes for five of six patients were equal to or smaller than normal, and CV values were larger than normal.

Previous reports, 3738 based on stained slide observations, have attempted to correlate peripheral lymphocyte size and prognosis in CLL. Zacharski and Linman, ${ }^{37}$ Gray, Jacobs and Block, ${ }^{38}$ and Schrek and Donnelly39 reported that patients with large, abnormal lymphocytes have a more progressive disease and shorter survivals than patients with small lymphocytes. In the current study, the two cases of CLL with the largest MCVs were considered clinically to be in stage IV of their disease. It appears likely that unbiased lymphocyte volume analysis could help to validate the relation between the size of cells in patients with CLL and their prognosis.

Our study indicated that there was a great variation in cell size of lymphoblasts among and within cases of ALL. In addition, the data suggest that lymphoblasts from patients may cluster into at least two and perhaps three groups based on cell volume. We correlated cell size with the FAB classification of $\mathrm{ALL}^{35}$ and noted that the MCV of L1 lymphoro blasts was smaller than the MCV of L2 lympho-? blasts but not at a significant level. The lack of significant correlation between $\mathrm{MCV}$ and the FAB classification is not unexpected since the FAB classification considers other criteria besides size of blasts. However, we hope to correlate the MCV of blasts with duration of first remission and survival of our patients with ALL.

Pantazopoulos and Sinks ${ }^{5}$ and Murphy et al. ${ }^{40}$ attempted to correlate lymphoblast size and prognosis in childhood ALL. In both studies a total of 200 lymphoblasts on stained bone marrow smears were measured using an eyepiece micrometer. Cells with a diameter less than $12 \mu \mathrm{m}$ were classified as microlymphoblasts. Pantazopoulos and Sinks ${ }^{5}$ found a better prognosis when macrolymphoblasts were $10 \%$ or less of bone marrow cells in ALL patients. Murphy et al. ${ }^{40}$ reported no relation between the percentage of macrolymphoblasts and response to treatment or survival. The small number of cells measured, the tedious method used, and the susceptibility of cells toward distortion on slide preparations may explain the contrasting results. In light of the much improved prognosis of childhood ALL in recent years, clinical studies combining the most successful protocols with standardised, automated cell volume analysis could resolve the question of lymphoblast size versus prognosis. 
The average MCVs of the non-Hodgkin's lymphomas corresponded moderately well with the histological classification proposed by Rappaport. ${ }^{2}$ The MCVs of lymphocytes from patients with PDLL was slightly larger than lymphocytes from lymph nodes with reactive hyperplasia and peripheral blood mononuclear cells. In addition, the current study demonstrated that lymphocytes from patients with HL and BL had the largest MCV and lymphocytes from patients with MHLL had an intermediate MCV. We are aware that these observations are based on a small sample and agree that further study is necessary to confirm our findings. In general the standard deviations within and among cases of NHL were considerably larger than in reactive lymph nodes and peripheral blood mononuclear cells from normal individuals indicating the tremendous heterogeneity of cell sizes in these lymphomas.

The MCVs of normal and neoplastic cells were compared according to the origin of these cells. The data suggested that, with the exception of cells from patients with CLL, neoplastic T and B lymphocytes were more heterogeneous and often larger than normal $\mathrm{T}$ and $\mathrm{B}$ lymphocytes.

To summarise, the current study demonstrated different MCVs among normal T lymphocytes, B lymphocytes and monocytes. Lymphocytes from patients with CLL were smaller than normal peripheral blood B lymphocytes and as a group showed no greater variation in size than normal B cells. In contrast, lymphoblasts from cases of ALL were larger than peripheral blood lymphocytes and showed considerable heterogeneity within and among individual cases. Lymphocytes from cases of NHL also demonstrated great variation in cell size within and among individual specimens. In general, there appeared to be an association between the MCVs of NHLs and the classification of lymphoma as proposed by Rappaport. We suggest that the sizing of cells from neoplastic lymphoproliferative disorders may be helpful in the future as a diagnostic and a prognostic procedure.

\section{References}

${ }^{1}$ Hayhoe FGJ, Cawley JC. Acute leukaemia: Cellular morphology, cytochemistry and fine structure. Clin Haematol 1972;1:49-94.

2 Rappaport H. Tumors of the hematopoietic system. Atlas of tumor pathology Section III, Fascicle 88. Washington DC: Armed Forces Institute of Pathology, 1966.

${ }^{3}$ Dorfman RF. Classification of non-Hodgkin's lymphomas. Lancet 1974 ; : $: 1295-6$.

${ }^{4}$ Lukes RJ, Collins RD. Immunologic characterization of human malignant lymphomas. Cancer 1974;34:1488-503.

${ }^{5}$ Pantazopoulos N, Sinks L. Morphological criteria for prognostication of acute lymphoblastic leukaemia. Br J Haematol 1974;27:25-30.
${ }^{6}$ Mathe G, Pouillart P, Weiner R, Hayat M, Steresco M, Lafleur M. Classification and subclassification of acute leukemias correlated with clinical expression, therapeutic sensitivity and prognosis. Recent Results Cancer Res $1973 ; 43: 6-20$.

7 Zucker RM, Cassen B. The separation of normal human leukocytes by density and classification by size. Blood 1969;34:591-600.

${ }^{8}$ Westring D, Ladinsky I, Feick P. The volume distribution of human lymphocytes. Proc Soc Exp Biol Med 1969; $131: 1077-83$.

${ }^{9}$ Van Dilla MA, Fulwyler MJ, Boon IU. Volume distribution and separation of normal human leukocytes. Proc Soc Exp Biol Med 1967;125:367-70.

${ }^{10}$ Tivey $\mathrm{H}$, Li JG, Osgood EE. The average volume of leukaemic leukocytes. Blood $1951 ; 6: 1013-20$.

${ }^{11}$ Sipes CR, Chanana AD, Cronkite EP, Joel DD, Schiffer LM. Studies on lymphopoiesis VII. Size distribution of bovine thoracic duct lymphocytes. Proc Soc Exp Biol Med 1966;123:158-61.

12 Moon R, Phillips RA, Miller RG. Sedimentation of volume analysis of human bone marrow. Ser Haematol 1972;2:163-78.

${ }^{13}$ Loos H, Blok-Schut B, Kipp B, Van Doorn R, Meerhof L. Size distribution, electronic recognition and counting of human blood monocytes. Blood 1976;48:743-53.

${ }^{14}$ Humphries RK, Miller RG. Volume analysis of human peripheral blood leukocytes. Ser Haematol 1972;2:14262.

${ }^{15}$ Hughes-Jones NC, Norley I, Young JMS, England JM. Differential white cell counts by frequency distribution analysis of cell volumes. J Clin Pathol 1974;27:623-5.

${ }^{16}$ Gauthier J, Harel P, Belanger C, Frayse J. Human leukocytes: their size distributions and mean cell volumes. Can Med Assoc J 1967;97:793-6.

17 Gauthier J, Harel P, Brosseau C. Leukocyte mean corpuscular volume in the differential diagnosis of acute leukemia. Can Med Assoc J 1973;109:187-9.

18 Ben-Sasson S, Patinkin D, Grover N, Doljanski F. Electrical sizing of particles in suspensions IV. Lymphocytes. J Cell Physiol 1974;84:205-14.

19 Nelson DA, Davey FR. Leukocytes peroxidase. In: Williams WJ, Beutler E, Erslev AJ, Rundles R, eds. Hematology. New York: McGraw-Hill, 1977:1627.

${ }^{20}$ Nelson DA, Davey FR. Sudan black B staining. In: Williams WJ, Beutler E, Erslev AJ, Rundles R, eds. Hematology. New York: McGraw-Hill, 1977:1629.

${ }^{21}$ Davey FR, Nelson DA. Periodic acid-Schiff (PAS) stain. In: Williams WJ, Beutler E, Erslev AJ, Rundles R, eds. Hematology. New York: McGraw-Hill, 1977:1630.

${ }^{22}$ Boyum A. Isolation of mononuclear cells and granulocytes from human blood. Scand J Clin Lab Invest [Suppl] 1967; $21: 77-89$.

${ }^{23}$ Gmelig-Meyling F, Ballieux R. Simplified procedure for the separation of human $\mathrm{T}$ and non-T cells. Vox Sang 1977;33:5-8.

${ }^{24}$ Brown G, Greaves MF. Cell surface markers for human T and B lymphocytes. Eur J Immunol 1974;4:302-10.

${ }_{25}$ Julius MH, Simpson E, Herzenberg LA. A rapid method for the isolation of functional thymus-derived murine lymphocytes. Eur J Immunol 1973;3:645-9.

26 Wolos JA, Davey FR. Function of lymphocyte subpopulations in chronic lymphocytic leukaemia. Activity in the allogeneic and autologous mixed lymphocyte reaction. Cancer 1980;45:893-8.

27 Jondal M, Holm G, Wigzell H. Surface markers on human $T$ and B lymphocytes: I. A large population of lymphocytes forming non-immune rosettes with sheep red blood cells. J Exp Med 1972;136:207-15.

${ }^{28}$ Papamichail M, Brown JC, Holborow EJ. Immunoglobu- 
lins on the surface of human lymphocytes. Lancet 1971; ii:850-2.

29 Yam LT, Li CY, Crosby WH. Cytochemical identification of monocytes and granulocytes. Am J Clin Pathol 1971; 55:283-90.

${ }^{30}$ Dock NL, Davey FR. Peripheral blood monocytes in the autologous mixed lymphocyte reaction. Clin Immunol Immunopathol 1980;17:123-31.

31 Goldberg J, McGuire LA, Dock NL, Williams WJ, Davey FR. Purification of human peripheral blood colony forming cells (CFUc). Exp Hematol 1980;8: 1086-93.

${ }^{32}$ MacDermott RP, Chess L, Schlossman SF. Immunologic functions of isolated human lymphocyte subpopulations $\mathrm{V}$. Isolation and functional analysis of a surface Ig negative, $\mathrm{E}$ rosette negative subset. Clin Immunol Immunopathol 1975;4:415-25.

${ }^{33}$ Steel R, Torrie J. Principles and procedures of statistics. New York: McGraw-Hill, 1960.

${ }^{34}$ Rai KR, Sawitsky A, Cronkite EP, Chanana AD, Levy RN, Pasternack BS. Clinical staging of chronic lymphocytic leukemia. Blood 1975;46:219-34.

${ }^{35}$ Bennett JM, Catovsky D, Daniel MT, Flandrin G, Galton DAG, Gralnick HR, Sultan C. Proposals for the classification of the acute leukaemia. $B r J$ Haematol 1976;33:451-8.

${ }^{36}$ Braylan RC, Fowlkes BJ, Jaffe ES, Sanders SK, Berard CW, Herman CT. Cell volumes and DNA distributions of normal and neoplastic human lymphoid cells. Cancer $1978 ; 41: 201-9$.

37 Zacharski LR, Linman JW. Chronic lymphocytic leukemia versus chronic lymphosarcoma cell leukemia. Am J Med $1969 ; 47: 75-81$.

${ }^{38}$ Gray J, Jacobs A, Block M. Bone marrow and peripheral blood lymphocytosis in the prognosis of chronic lymphocytic leukemia. Cancer 1974;33:1169-78.

${ }^{39}$ Schrek R, Donnelly W. Cytology in lymphosarcoma cell leukemia. Am J Clin Pathol 1971;55:646-54.

${ }^{40}$ Murphy SB, Borella L, Sen L, Mauer A. Lack of correlation of lymphoblast cell size with presence of $\mathrm{T}$-cell markers or with outcome in childhood acute lymphocytic leukaemia. Br J Haematol 1975;31 :95-101.

Requests for reprints to: Professor FR Davey, Division of Clinical Pathology, State University of New York, Upstate Medical Center, 750 East Adams Street, Syracuse, New York 13210, USA. 